\title{
Historical Landmarks of the Evolution of Forensic Medicine and Comparative Development of Medico- Legal Services in Sri Lanka
}

\author{
Rohan P Ruwanpura $^{*}$, Muditha Vidanapathirana ${ }^{2}$ \\ ${ }^{1}$ Office of Judicial Medical Officer, Teaching Hospital, Karapitiya, Galle, Sri Lanka. \\ ${ }^{2}$ Department of Forensic Medicine, Faculty of Medical Sciences, University of Sri \\ Jayewardenepura
}

Keywords: History, Forensic Medicine, Forensic Science, Medico-legal System, World, Sri Lanka

Copyright: @ 2017 with the Medico-legal Journal of Sri Lanka.

This is an open-access article distributed under the terms of the Creative Commons Attribution 4.0 International License, which permits unrestricted use, distribution and reproduction in any medium provided the original author and source are credited.

\author{
Funding: None \\ Competing interests: None \\ Received: 24 April 2018
}

Accepted revised version: 30 May 2018 Published: 30 June 2018

*Corresponding author: Ruwanpura PR, Email: rohanruwanpura_fom@pgim.cmb.ac.lk, $₫$

https://orcid.org/0000-0003-3656-6471

Cite this article as: Ruwanpura PR, Vidanapathirana M. Historical landmarks of the evolution of Forensic Medicine and comparative development of Medico-legal services in Sri Lanka. Medico-Legal Journal of Sri Lanka, 2018; 6(1): 1-16

DOI: http://dx.doi.org/10.4038/mljsl.v6i1.7366

\section{Introduction}

History of any discipline, including medical sciences, is really valuable for us to understand the evolution of the subject through different stages of existence, how the present state of development has been achieved, appreciate the contributions of our ancestors and finally allow us to learn through the mistakes. As it says history helps us to understand the present, teaches us to think contemplating the experience that came before our time. ${ }^{[1]}$ The first available elements of medical science refer back to ancient Egyptian times of 4000 years BC. The English term 'Forensic' appeared to be originated in

the mid- $17^{\text {th }}$ century from Latin term forensis (means in open court or public forum). The forensic medicine at present incorporates clinical forensic investigations, autopsy and supporting disciplines such as forensic science. It appeared from the historical evidence that clinical forensic medicine existed much earlier than the materialization of forensic pathology revolts to the examination of corpses.

Thus the purpose of the forensic medicine is to fulfil medical needs of the legal system, without any doubt, the instigation of forensic had to coincide with the establishment of laws and regulations in olden human societies. In fact, the fundamental elements of medical law related to the initiation of medical jurisprudence are also found among the documentary evidence of prehistoric era. The objective of the present paper is to elaborate on important landmarks of the development of medical jurisprudence with specific empathies to individual contributions to major scientific advancements, and comparative development of legal medicine in Sri Lanka.

\section{The terminology}

According to Cambridge Dictionary, the word forensic is related to scientific methods of solving crimes, involving examining the objects or substances that involve in the crime. Hence, forensic medicine uses knowledge of medical science for the purposes of solving crimes. Medical jurisprudence or legal medicine as it establishes in Central Europe is the branch of science and medicine involving the study and application of scientific and medical knowledge to legal problems, such as inquests, and in the field of law. ${ }^{[2]}$ 


\section{Forensic medicine in prehistoric societies}

The first elements of medicinal knowledge of the society are found among historical remnants of the primary civilizations in Mesopotamia (Fig. 1). ${ }^{[3]}$ They had a fair knowledge about diseases, drugs and there were state paid physicians of all specialiities. ${ }^{[4]}$

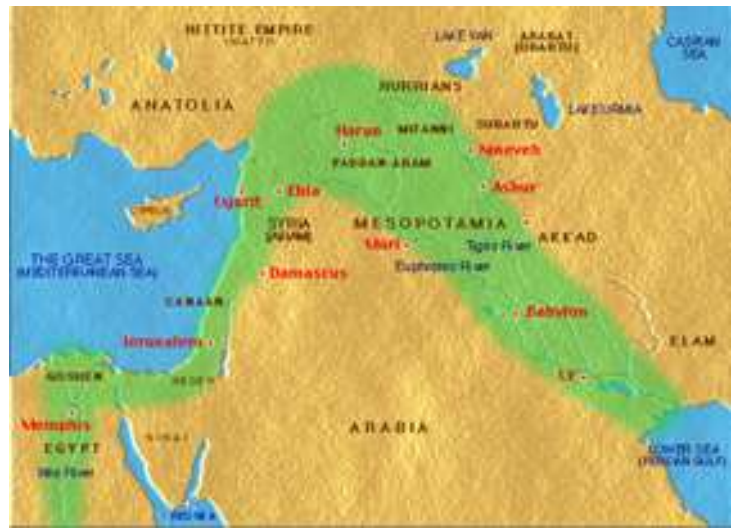

Figure 1: Primary civilizations in Mesopotamia

Even prior to Mesopotamian era, the paintings in the Cave of Lascaux in Pyrenees mountain of France contained a figure of a long man with the head of a bird, which is widely believed to be the "Shaman" who was in charge of health, life and death. The cave of Lascaux is the oldest evidence about the art of medicine, dated back to 15,000 years (Fig. 2). The opening of the skull to release evil spirits so called practice of trepanning has been evident among primitive communities in many parts of the world around 12,000 years BC. However, the art of medicine in early human society was mostly based on spiritual concepts consist of magic, god, religion, use of charms and talismans etc.

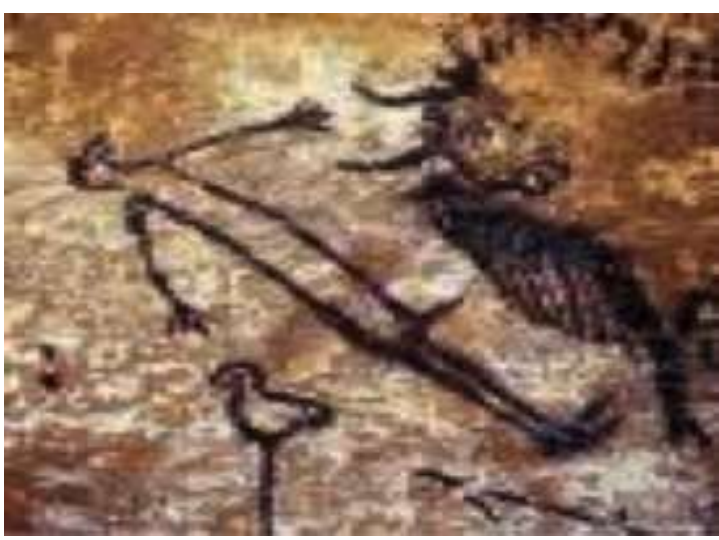

Figure 2: Picture of Shaman in the Cave of Lascaux (http://www.bradshawfoundation.com/cave_art_an _intuition_of_eternity/decent_into_the_cave/shama nistic_visionary_experience.php)

The practice of medicine as a science is allied with the grand title of medicine, the Imhotep, a grand vizier and physician to the Pharaoh around $3000 \mathrm{BC}$, who has treated over hundreds of diseases and performed surgeries and practised dentistry as well (Fig. 3).

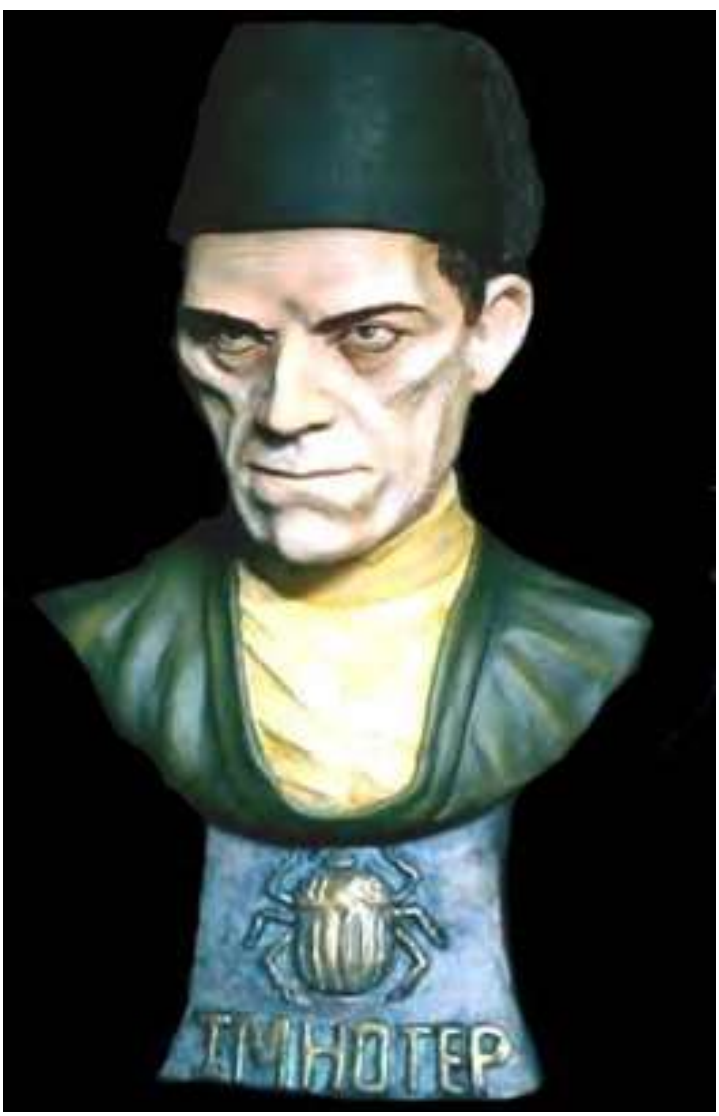

Figure 3: Imhotep, a grand vizier and physician

Perhaps, the oldest record pertaining to medico-legal matters is the Code of Hammurabi by King of Babylon, which is dated at around 2,200 BC (Fig. 4). This code written in cuneiform letters includes details of the regulation of medical practice, initial elements of medical malpractice and patient's right for the punishment of the Doctor and compensation.

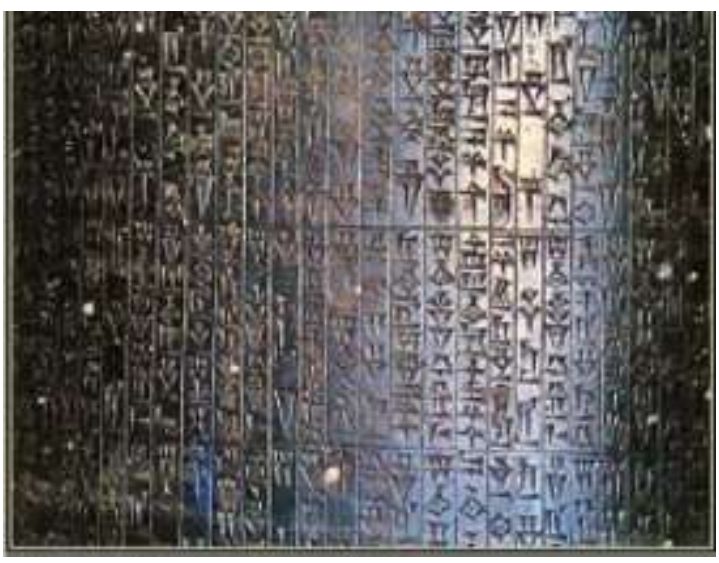

Figure 4: Code of Hammurabi 
According to provisions of the Code of Hammurabi, the practice of medicine in Egypt was subject to strict legal provisions, criminal abortion was punishable by law and the Egyptians were mastered in the art of chemical preservation of dead bodies. The mummies of Paros's are well preserved even today.

Medical science during the prehistoric period has independently developed under Chinese dynasties. The earliest written records of Chinese medicine, the Huang-Di Nei-Jing dates back to about 5000 years. ${ }^{[5]}$ Furthermore, the progress of traditional Chinese medicine has a significant impact on all other systems in the world.

The fundamentals of medical jurisprudence are found among old Indian medical chronicles too. The first Indian medico-legal code "Dharmasastra" published around $2000-3000$ BC described the ineligibility of insane and a drunkard, very old, sick persons and children to give valid statements at the Courts $^{[6]}$. Interestingly, the legal validity of statements and fitness to take part in a court trial is a matter of extensive debate at present as well.

The development of medicine and ethical aspects of medical practice has significant influence by the introduction of Hippocratic Oath around $460-377$ BC. Hippocrates, the father of modern medicine, dominated the beginning of a period of remarkable scientific creativity, which lasted more than 700 years (Fig. 5). He is considered one of the greatest physicians of the world and who was first to attempt to separate the practice of medicine from religion and superstition. During Hippocratic era, a physician could be hired or even ordered to prepare poison to kill an enemy, especially when a ruler wanted to get-rid of his rival. Hippocrates taught against such improper conduct and taught his students to treat everyone with dignity and in a professional manner. The basic principles of Hippocratic Oath are admired in all parts of the world even after 25 centuries and serve as fundamentals of medical ethics in the modern world.

Further, Hippocrates used arsenic sulphide to treat stomach ulcers and abscesses. ${ }^{[7]}$ Arsenic is considered as a healer as well as a poison. Therefore, this management was called the deadly cure.

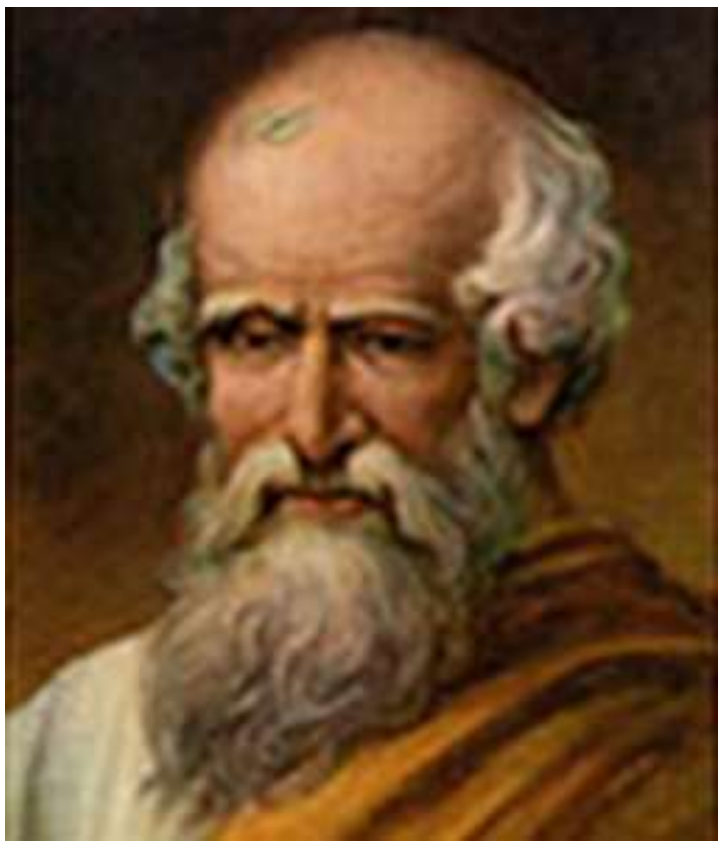

Figure 5: Hippocrates - Father of Modern Medicine

Socrates was another Greek philosopher. The trial of Socrates (399 BC) was held to determine the philosopher's guilt of two charges: "Introducing new ideals" and "Failing to acknowledge the gods". ${ }^{[8]}$ At the trial, the majority of the jurors voted to convict him of the two charges. Consistent with common legal practice, jurors then voted to determine his punishment and agreed to sentence to death by providing a poisonous beverage of hemlock. Socrates was given the deadly poison hemlock by Greek rulers. This was the first famous case of capital punishment by poisoning. ${ }^{[9]}$ Further, this was one of the earliest famous trials in the world.

The development of medical practice including legal medicine is essentially dependent upon advancement of science and technology, and application of scientific knowledge to resolve crimes became another historic landmark of the evolution of forensics. The discovery of the "principle of buoyancy" or the "Archimedes' principle" by the Greek scientist Archimedes of Syracuse (287-212 BC) is the earliest recorded instance when knowledge of natural sciences has been applied for the detection of crime and conviction of criminals. ${ }^{[10]}$ Since then the use of scientific advancements for resolution of crimes became an integral part of the criminal investigations.

Another name that often encountered in medicolegal history is a Julius Caesar, a Roman Empire around $44 \mathrm{BC}$. Caesar was stabbed and killed by his ministers (Fig. 6). Antistius, an ancient physician who examined Caesar's body concluded that out of 
23 stabs only one wound, the one in the chest between 1 st and 2 nd ribs found to be fatal. ${ }^{[1]}$ The postmortem examination of Caesar's body is the earliest recorded incident of examination of a dead body of a murder victim by the physician probably for the patho-physiological purposes as there were no hints about a judicial order or state request being issued for such examination. Interestingly, Julius Caesar who was believed to be born with the first caesarian section had been crystallized as the subject of the first pathological autopsy.

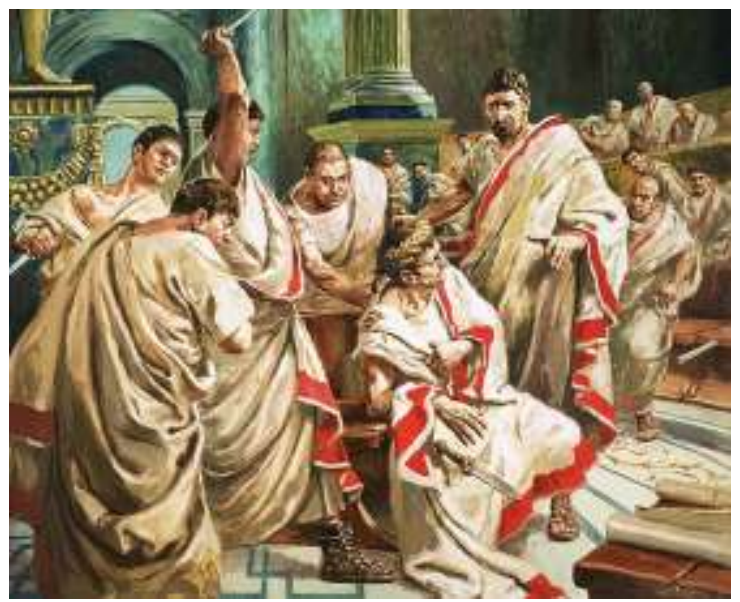

Figure 6: Assassination of Julius Caesar

The ultimate basis of forensic pathology is centred in dissection and systemic examination of dead bodies, more precisely speaking, in morbid anatomical explorations. In the first half of the third century B.C, two Greeks, Herophilus of Chalcedon and his junior contemporary Erasistratus of Ceos, became the last ancient scientists to perform series of systematic dissections of human cadavers for the study of the architecture of human body. ${ }^{[12]}$ Although dissections were motivated by self-interest in a study into the structure of the human body, their anatomical and physiological discoveries became extraordinary. ${ }^{[13]}$ Unfortunately, the dissection of a dead body considered to be a serious crime in majority antiquated jurisdictions and there were very few or no followers for these scientists until medieval European era. These historical data confirms that the autopsy examination is also more than 25 centuries old, perhaps, very likely to be performed by applying the dissection methodologies exactly similar to what we practice today.

The fundamentals of Forensic Medicine have been nurtured with conceptual contributions of great physicians in the past. The concepts of Greek Physician Aelius Galen, ${ }^{[14]}$ surgeon and philosopher in the Roman Empire, who existed during the $2^{\text {nd }}$ century had significantly influenced and strengthened the scientific knowledge related to medical practice and made available in an amazing volume of written works. His influence lasted over 40 generations. According to Galen, body systems are based on the balance of four fluids and a wound is a "Window to the body". Galen has performed dissection of animals in his extensive medical research and also scientifically compared what he found at autopsy, with what he had seen on his patients, and what they had complained of, what we call clinico-pathological correlation today. Unfortunately, a broad-minded great master of his art succumbed to dogmatism at latter stages, buoyed by his followers and commentators.

The Chinese Shennong Emperor's Classic of Materia Medica in 100 AD contained an information about poisons including aconite, arsenic and opium, viz; the nitty-gritties of forensic toxicology. ${ }^{[15]}$ The first real evidence that a special branch of medicine devoted to the support of judicial work was indeed taking shape dates from the thirteenth century AD comes from China. The Old Chinese medicine including some aspects of jurisprudence seemed to be independently evolved and then spread over other parts of the world.

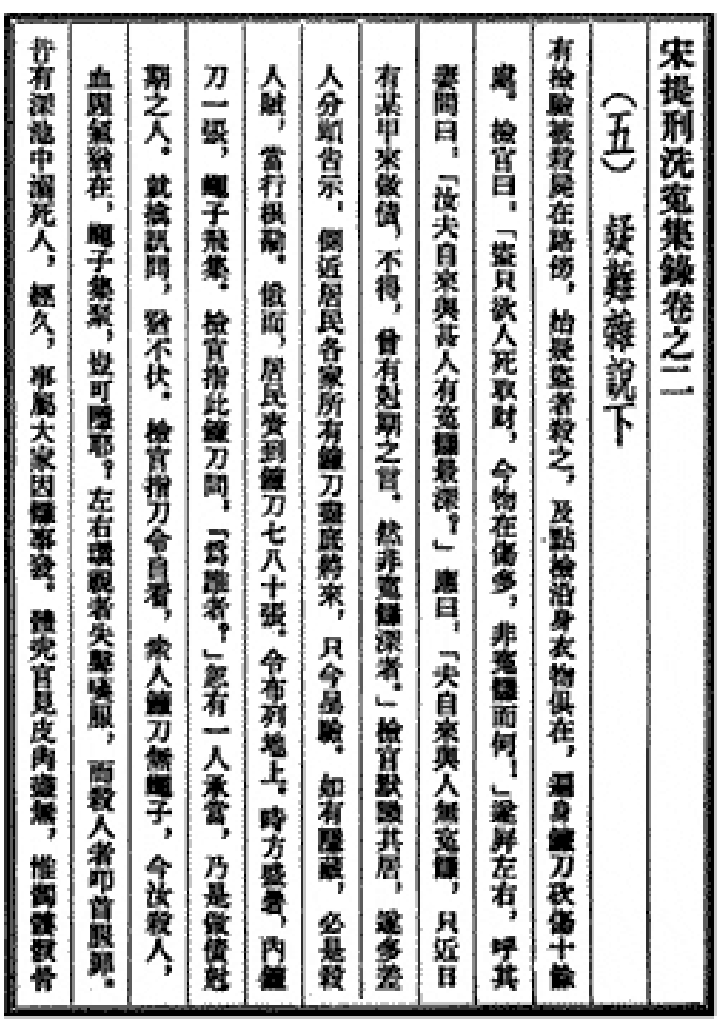

Figure 7: The world first forensic handbook Hsi Yuan $\mathrm{Lu}$

A handbook titled Hsi Yuan Lu (Fig. 7), authored by the Chinese medical expert Hsu Chichtsi regarding the application of medical knowledge to the solving of crimes and to the work of the courts contains valuable instructions for the examination of corpses. 
It deals with the various kinds of wounds and describes how to ascertain whether a person had been killed by strangulation or drowning. The book describes the difference between antemortem and postmortem drowning, which is a matter of controversy even in the $21^{\text {st }}$ century.

\section{Forensic medicine in the medieval period}

Medieval period in Europe starts with the fall of the Western Roman Empire in the $5^{\text {th }} \mathrm{AD}$ (476 AD) and merged into the Renaissance. ${ }^{[16]}$ During this period, there had been no significant development in any field. Then the renaissance of Europe takes place in 1300 with the advancement of arts, poets, dramas etc. A parallel such development was found in Sri Lanka too, under King Parakramabahu the $\mathrm{VI}^{\text {th }} .{ }^{[17]}$ Then in the $15^{\text {th }}$ Century (the 1400s), the industrial revolution took place in Europe and a rapid development of the forensic medicine and science was taken place.

\section{The modern era of development}

The first clearly documented court-ordered postmortem examination took place in Bologna, Italy, in 1302, with the participation of two physicians and three surgeons on the body of Azzolino, whose death demanded an official inquiry. ${ }^{[18]}$ Unarguably, Vein is one of the leading European centres, where flickers of modern medicine were instituted. The Italian professor Galeazzo di Santa Sophie (1404) performed the first post-mortem autopsy demonstration in the University of Vein for the purposes of teaching at the Heiligen-Geist Spital (Fig. 8), Vienna University of Technology today. ${ }^{[19]}$ The autopsies are demonstrated for a fee for medical students (Fig. 9).

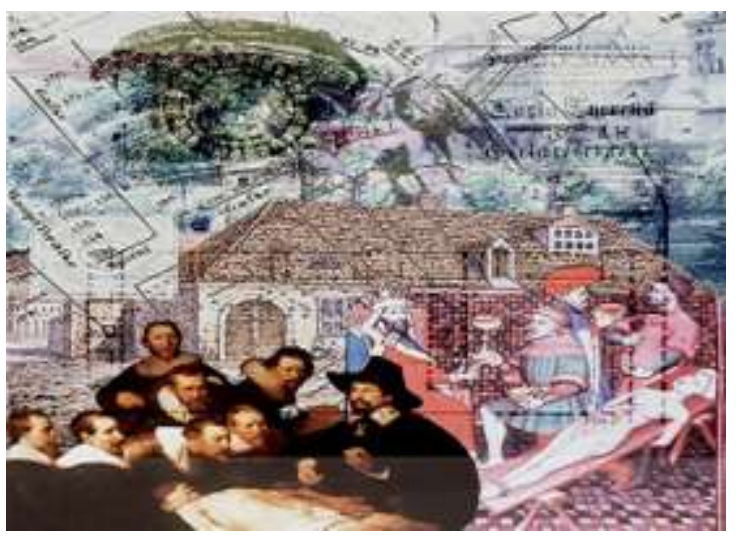

Figure 8: Centre for forensic medicine at University of Vein

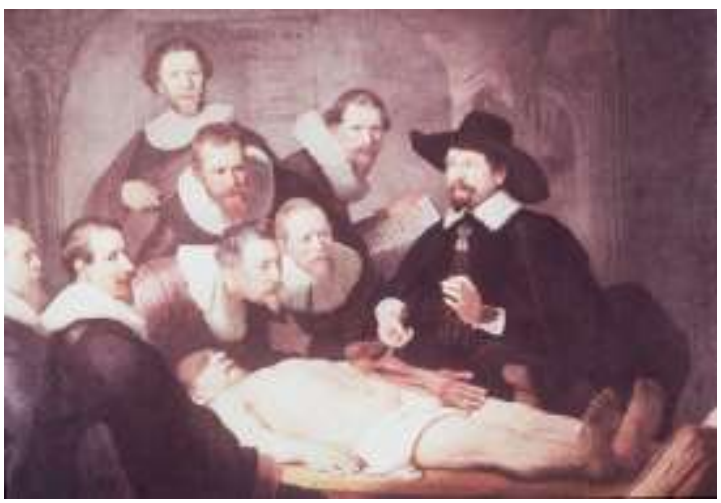

Figure 9: Post-mortem by Dr Tulp - painting by Rembrandt ${ }^{[20]}$

The rapid development of the technology in postmedieval Europe had strong directives on utilizing medical knowledge for the legal purposes. The basis of the German law known as Constitutio Bambergensis Criminalis (Fig. 10) was drawn up by Johann Freiherr von Schwarzenberg in the diocese of the Bishop of Bamberg in 1507. The legal draft officially acknowledged the usefulness of physicians in court cases involving infanticide and bodily injury.

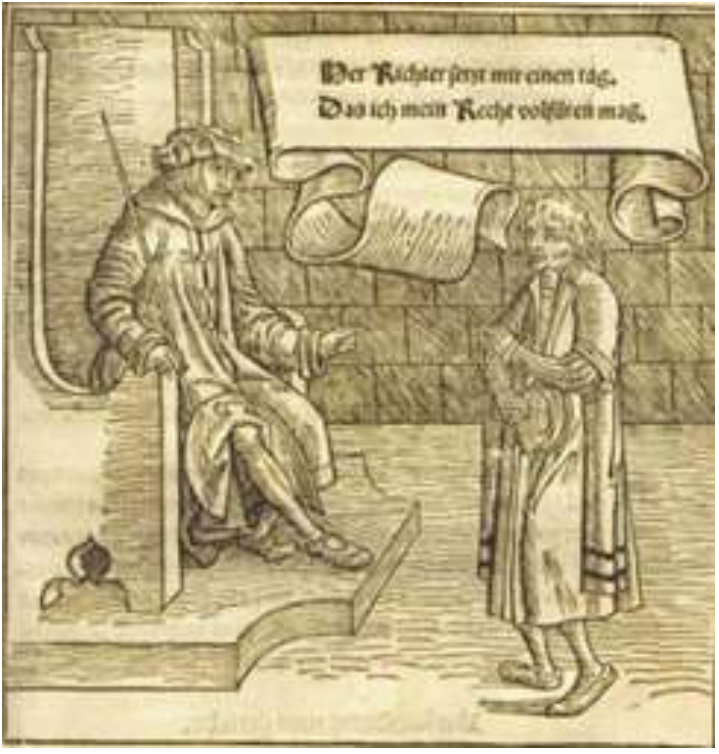

Figure 10: Constitutio Bambergenesis Criminalis

It became the model for a far more extensive penal code, the Constitutio Criminalis Carolina, also known as The Criminal Jurisdiction of Emperor Charles V and the Holy Roman Empire, issued by Charles V in 1532 for all the lands included within his mighty empire. According to provisions of the constitution, one of the physician's principal functions was to decide whether a defendant was strong enough to be put to torture. ${ }^{[21]}$ 
The first systemic manual on forensic medicine, "Quaestiones medico-legales" a three-volume publication was authored by leading Italian forensic medical expert Paolo Zacchia (1584 - 1659). ${ }^{[22]}$

The essence of forensic pathology originates from morbid anatomical dissections, perhaps dissection of human remains was suppressed to a certain degree due to restrictions imposed by ancient rulers, probably due to the risk of infections and sacred believes about dead. The expansion of morbid anatomy was predominantly rested upon brave efforts of a few individual scientists. During the period from 1489 to 1513, in the undercroft of Santa Maria Nuova, Leonardo da Vinci dissected more than 30 bodies belong to both genders and all ages. Dissections were done under a messy environment of odious sights and awful odours of decomposing corpses. Due to restrictions, Leonardo performed his dissections at night by candlelight, which made them even more ghoulish. He had to pay grave robbers to bring him bodies for his anatomical and pathological studies. Da Vinci described the coronary sinuses almost 200 years before Valsalva gave them his name, and, 120 years before Harvey, was surely only a heartbeat away from grasping the idea of the circulation of the blood (Fig. 11). ${ }^{[23]}$

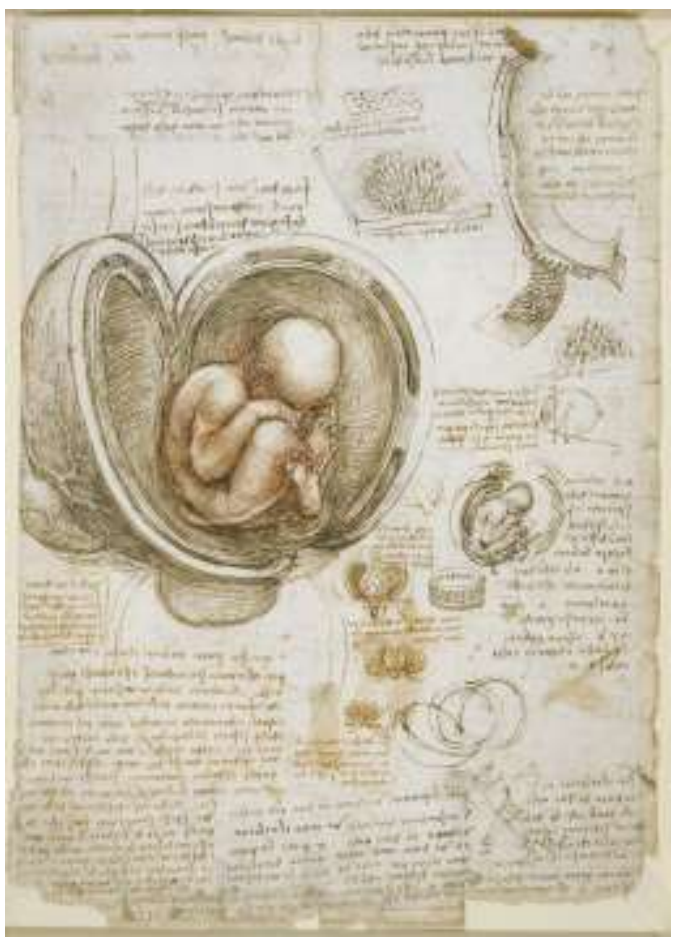

Figure 11: Paintings of Da Vinci at Royal collection

Andreas Vesalius a Belgian anatomist and physician, 1514 - 1564, transformed anatomy into a subject that trusted on direct observations of human dissections. In 1539, a Paduan Judge became interested in Vesalius' work and made bodies of executed criminals available to him. Vesalius had authored one of the most influential books on human anatomy, De Humani Corporis Fabrica (Fig. 12), that made him to be considered the founder of modern anatomy. ${ }^{[24]}$

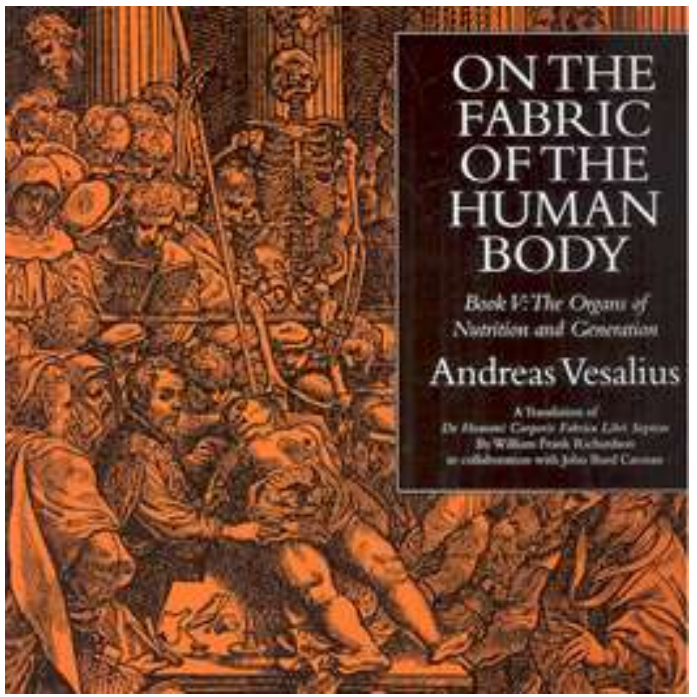

Figure 12: De Humani Corporis Fabrica (English title page)

Toxicology is an integral companion of forensic medicine. Forensic toxicology is branched out from medical toxicology and pharmaceutical sciences, which has been evolving since Egyptian times. However, the identity of medical toxicology commenced with the concept of Paracelsus, who brought knowledge of chemistry into the medicine. Philippus Aureolus Theophrastus Bombastus von Hohenheim (1493-1541), who called himself Parasecelsus, is the person who pioneered the use of minerals and other chemicals in medicine. According to his school of medical chemistry "a poison in the body would be cured by a similar poison," (principle of similitude) but the dosage is very important." In other words, Paracelsus says ${ }^{[25]}$ "All substances are poisons; there is none that is not a poison. The right dose differentiates a poison from a remedy."

France also established its medico-legal services in late $16^{\text {th }}$ century with the enactment of laws for development of legal medicine as an academic discipline. However, by 1690, medico-legal officers became corrupt and progress of the subject was almost in a standstill until the post-revolution era. ${ }^{[26]}$

In the eighteenth century, the Italian anatomist Giovanni Battista Morgagni (1682-1771) had begun dissecting the bodies of the dead and comparing the alterations in their organs with the symptoms of the diseases that had caused death (Fig. 13). In 1761 (i.e. in the eightieth year of his life!), he published a book on the 640 post-mortem dissections he had conducted. He thus was the founder of pathology. 




Figure 13: Giovani Morgagni

Mary Blandy was a female murderer in England. In 1751, she poisoned her father with Arsenic. She claimed that she thought the Arsenic was a love potion that would make her father approve of her relationship with an army officer. The trial on 3 March 1752 was of forensic interest. Dr Anthony Addington gave expert evidence about the Arsenic poisoning. Dr Addington's testing would be rudimentary by today's standards but was quite fascinating in the $18^{\text {th }}$ century. On 6 April 1752 , Blandy was hanged outside Oxford Castle prison for committing homicide (Fig. 14). ${ }^{[27]}$

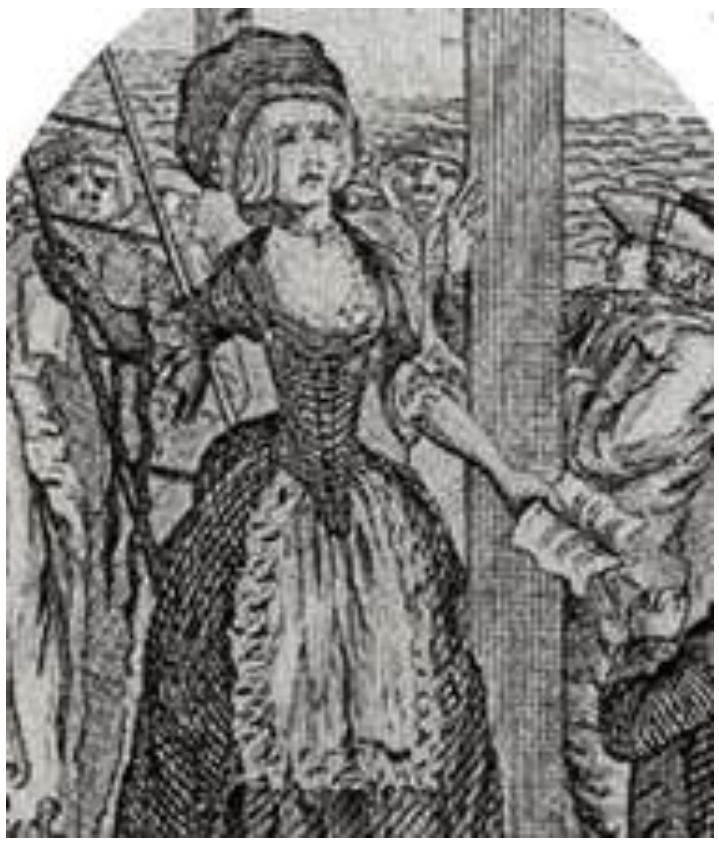

Figure 14: Mary Blandy

The seventeenth century European scientists have further nurtured the forensic science with their fabulous contributions. A German medico-legal expert Johann Ludwig Casper [1796 - 1864] who was appointed as a professor at the Medicina Forensis and Publica and then became the director of an educational institution for forensic medicine in 1841 has published several volumes on forensic medicine based on his personal experience that included number of coloured illustrations (Figure $15){ }^{[28]}$

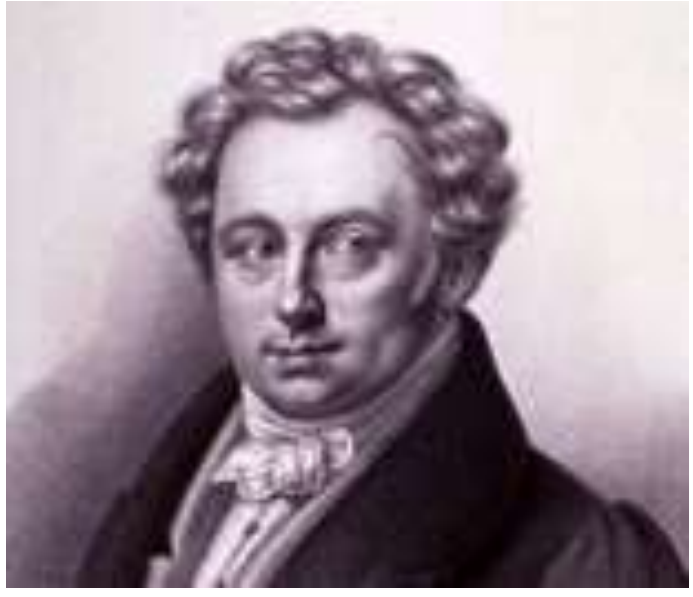

Figure 15: Johann Ludwig Casper (1796-1864)

A Spanish scientist Mathieu Joseph Bonaventure Orfila (1787-1853) is another remarkable exponent of the field forensic medicine due to his contributions on toxicology (Fig. 16). He is the founder of the science of toxicology. It has been customary during that time to call upon a forensic expert to examine the corpse and food items in a case of suspected poisoning. Orfila worked to make chemical analysis a routine part of forensic medicine and made studies of asphyxiation, the decomposition of bodies, and exhumation. ${ }^{[29]}$ The commonest type of poison used was arsenic, but there were no reliable ways of testing for its presence. In 1832, chemist James marsh designed a test for arsenic and used it to solve a murder crime. Orfila argued that arsenic in the soil around graves could be drawn into the body and be mistaken for poisoning and created new techniques and refined existing techniques in his first treatise, Trait des poisons, greatly enhancing their accuracy.

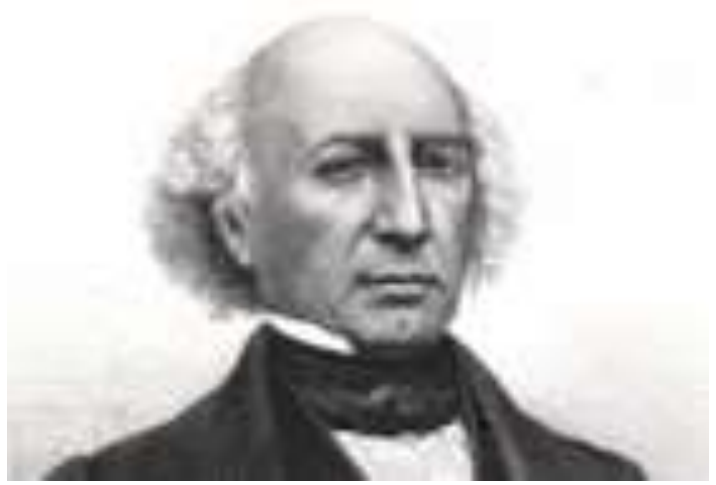

Figure 16: Mathieu Orfila 
In 1840, Marie LaFarge was tried for the murder of her husband using Arsenic. Orfila was asked by the court to investigate. He showed the shortcomings of the previous investigation and discovered that there was Arsenic in the body. LaFarge was found guilty. ${ }^{[30]}$

Jean Servais Stas was a Belgian analytical chemist who co-discovered the weight of the carbon. In 1850, Stas gave the evidence that the Belgian Visart de Bocarme killed his brother-in-law by poisoning with nicotine. Stas detected nicotine from oral burns. $^{[31]}$

Marie Guillaume Alphonse Devergie (1798-1879), originally a French dermatologist is also reckoned to be one of the founders of forensic medicine. He was co-publisher of the medico-legal journal with Orfila and in 1836 he published a two-volume book on judicial medicine called Medecine legale, theorique et pratique ${ }^{[32]}$.

The development of forensic medicine in the UK appeared to be influenced by scientific discoveries of Central Europe. It began at the end of the 18th century, long after its development in Germany, Italy, France, and other countries in Europe. ${ }^{[33]}$ There are a couple of names associated with enrichment of British Forensic Medicine. Alfred Swaine Taylor [1806 - 1880] was an English toxicologist and medical writer, who has been called the "father of British forensic medicine. ${ }^{[34]} \mathrm{He}$ was also an early experimenter in photography. He published textbooks on medical jurisprudence and toxicology, contributed to the Dublin Quarterly Journal and medical periodicals, and edited the Medical Gazette. He appeared as an expert witness in several widely reported murder cases.

Sir Arthur Ignatius Conan Doyle (Fig. 17) was a British writer and physician, most noted for creating the fictional detective Sherlock Holmes in 1886. These are generally considered milestones in the field of crime fiction. ${ }^{[35]} \mathrm{He}$ is also known for writing the fictional adventures of a second character he invented, Professor Challenger.

In 1892 the world's first fingerprint bureau was established in Argentina after a well-publicised case where a bloody fingerprint identified a killer. The uniqueness of fingerprints had long been suspected, but in 1892 Francis Galton (Fig. 18) calculated the chances of identical prints were one in 64 billion. Therefore, he is considered as the "Father of fingerprinting". [36] Since then fingerprinting has been widely used in all parts of the world.

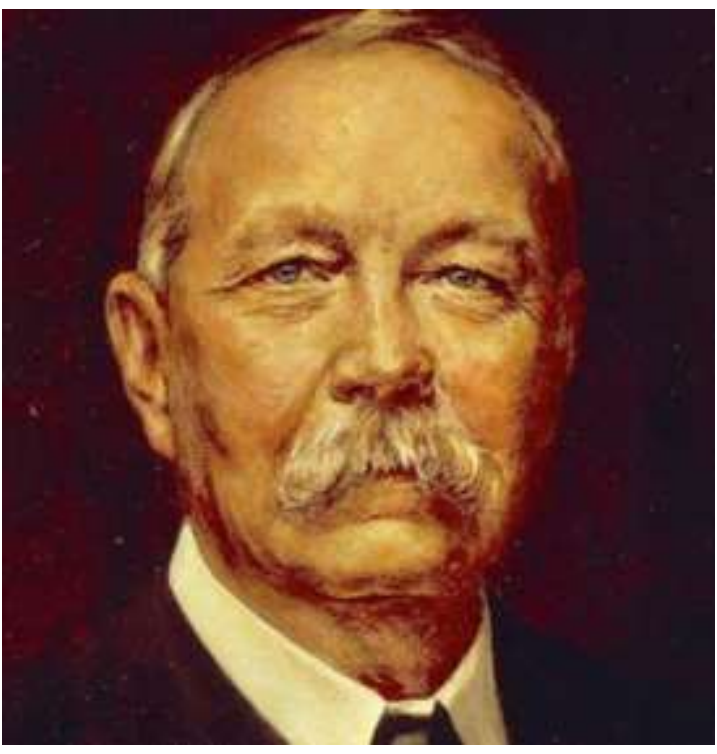

Figure 17: Sir Arthur Conan Doyle

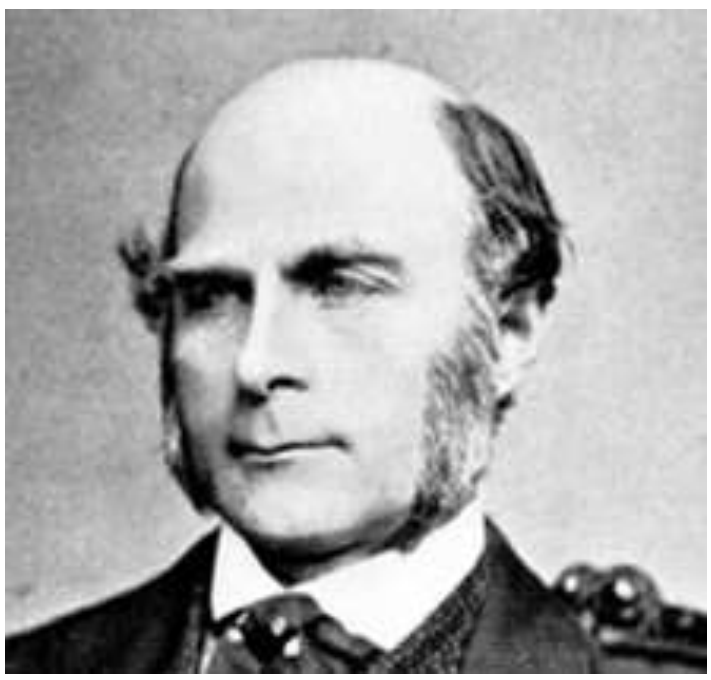

Figure 18: Sir Francis Galton

Karl Landsteiner (Fig. 19) was an Austrian biologist and physician. In 1900, he discovered main blood groups; A, B, AB, and O. ${ }^{[37]}$ In 1930, he received the Nobel Prize in Physiology and Medicine. In 1937, with his identification of the Rhesus factor ( $\mathrm{Rh}$ factor) with Alexander Wiener, he developed the modern classification of blood groups such as $\mathrm{A}+, \mathrm{A}-, \mathrm{B}+, \mathrm{B}-\mathrm{etc}$. These blood groups are used to analyze blood or bloodstains and identify the suspects or victims. Further, he enabled the doctors to transfuse blood without endangering the patient's life. Therefore, he is recognized the father of transfusion medicine. 


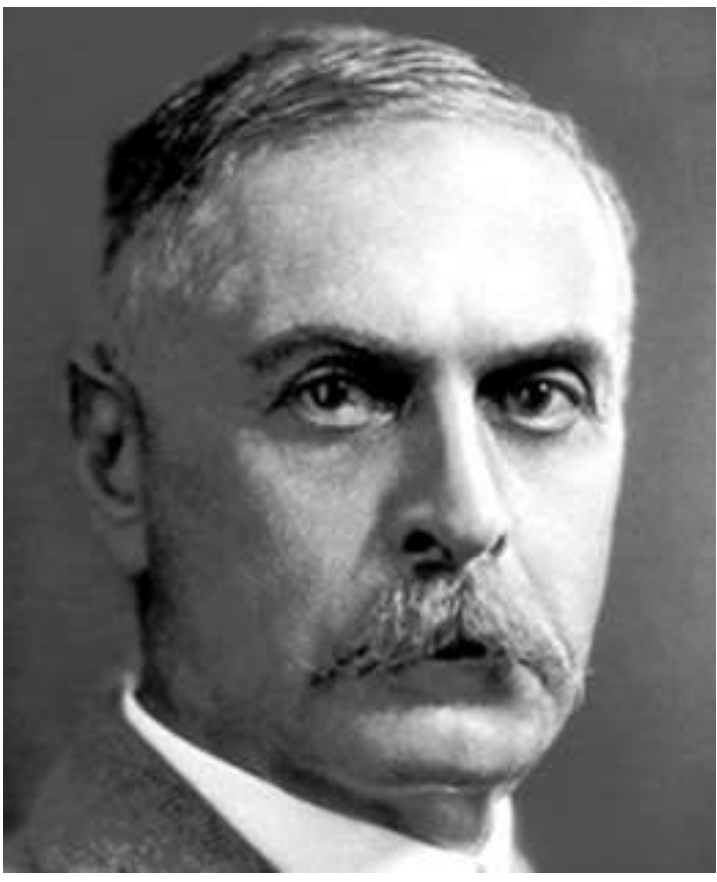

Figure 19: Carl Landsteiner

Alphonse Bertillon (Fig. 20) was a French police officer and biometrics researcher. He applied the anthropometry of anthropology to law enforcement creating an identification system based on physical measurements. ${ }^{[38]}$ In the past, criminals could only be identified by name or photograph. Anthropometry was the first scientific system used by police to identify criminals. Based on certain body measurements, in 1901, he developed a system to distinguish one individual from another. Therefore, he is considered the founder of anthropology.



Figure 20: Alphonse Bertillon, the founder of anthropology
Mikhail Semyonovich Tsvet was a Russian-Italian botanist who invented adsorption chromatography in 1906. Tsvet invented chromatography during his research on plant pigments. He used liquidadsorption column chromatography with calcium carbonate as adsorbent (which attaches to the surface of the paper) and ether as the solvent (the carrier of analytes along the paper) to separate chlorophylls and carotenoids. ${ }^{[39]}$ This was a huge invention because it paved the way for the subsequent inventions such as Thin layer chromatography (TCL), Liquid chromatography, Gas chromatography (GC), and GCMS etc.

A British medico-legal expert, Bernard Spilsbury [1877 - 1947] single-handedly brought criminal investigations into the modern age. ${ }^{[40]}$ In later years, Spilbury's dogmatic manner and his unbending belief in his own infallibility gave rise to criticism. Judges began to express concern about his invincibility in court and recent researches have indicated that his inflexible dogmatism led to miscarriages of justice. ${ }^{[41]}$

In 1910, the scientific concept "The exchange of materials between two objects that occurs whenever two objects come into contact with one another" by doctor professor Edmond Locard (Figure 21) became another revolutionary standpoint of forensic science, which lead to nicknamed him as Sherlock Holmes of France.

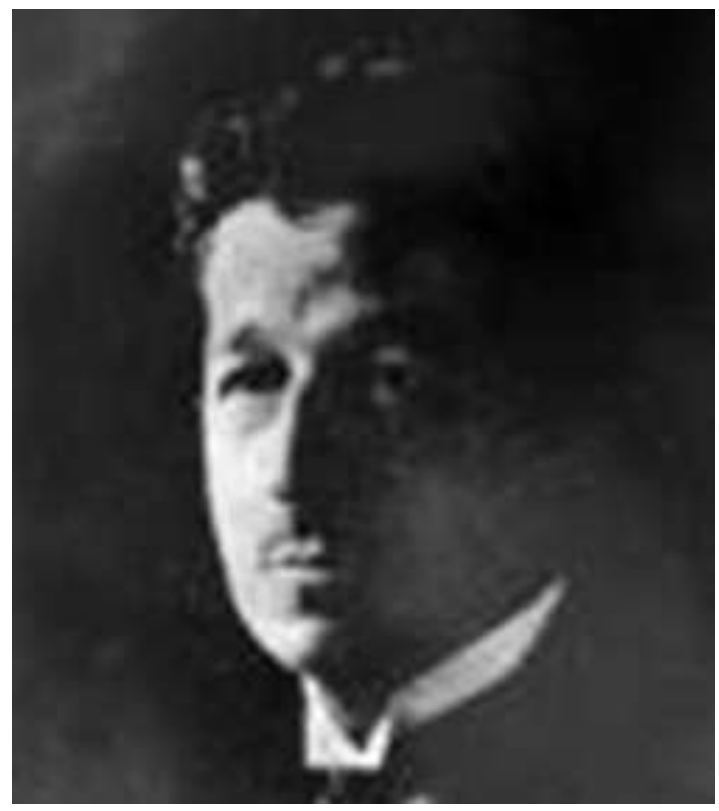

Figure 21: Edmond Locard

Albert Sherman Osborn (Fig. 22) is considered the father of the science of the 'Examination of the questioned document (EQD)'. His book "Questioned Documents" was first published in 1910 and revised as the second edition in 1929. 
Thereafter, documents are accepted as scientific evidence by the courts. ${ }^{[42]}$ On September 2, 1942 , Osborn founded the American Society of Examiners of Questioned Document (ASEQD) and became the society's first president. In Sri Lanka, at the Department of Government Analyst, we too have an "Examiner of Questionable Documents" (EQD) division.

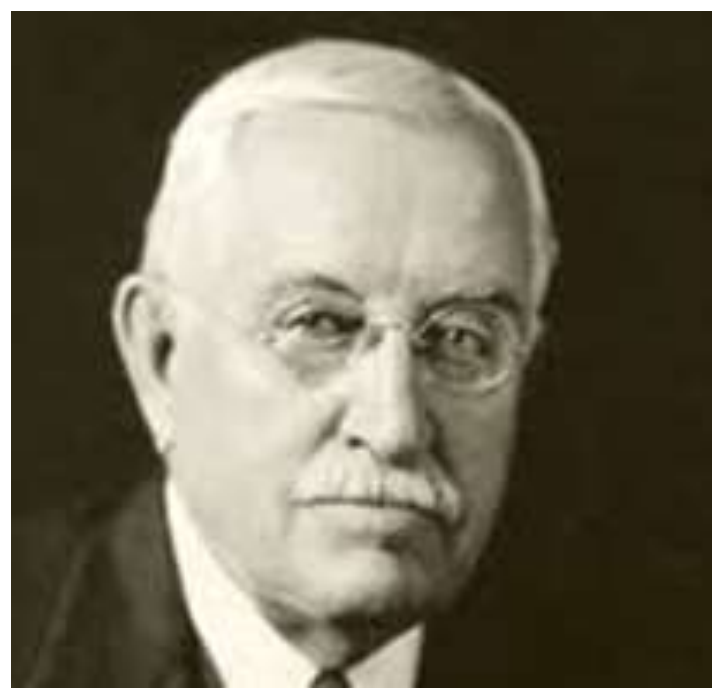

Figure 22: Albert Osborn: The father of the 'Examination of the questioned documents'

Leone Lattes (Fig. 23) was an Italian forensic serologist. In 1915, he developed a procedure to determine the blood group of dried bloodstains. ${ }^{[43]}$ Thereafter, blood groups could be used for identification of bloodstains in forensic investigations.

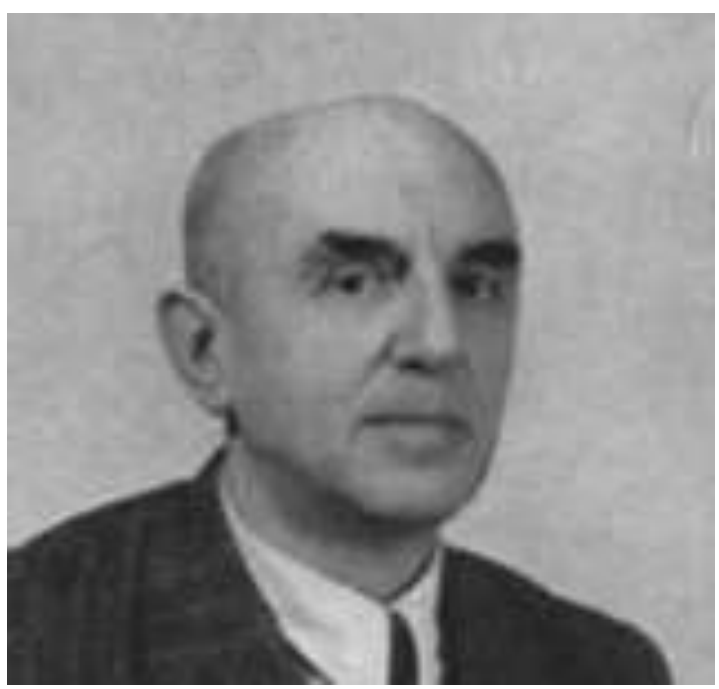

Figure 23: Leone Lattes

Calvin Hooker Goddard (Fig. 24) was an American army Colonel and a pioneer in forensic ballistics. In 1925 Goddard wrote an article on "Forensic
Ballistics" in which he described the use of the 'comparison microscope' in firearms investigations. Further, he is credited with the conception of the term "forensic ballistics". In April 1925, Goddard established the Bureau of Forensic Ballistics in New York. The Bureau was formed to provide firearms identification services throughout America. ${ }^{[4]}$

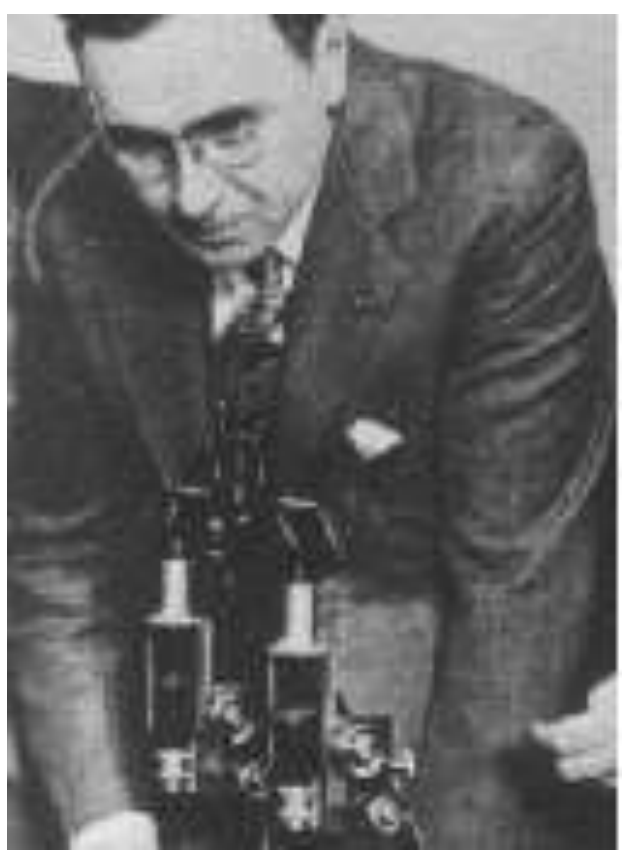

Figure 24: Goddard with the comparison microscope

In 1924 Edgar Hoover (Fig. 25) was appointed as the director of the Bureau of Investigation (BI), USA, the FBI's predecessor, and was instrumental in founding the FBI in 1935. In 1935, he was appointed as the first Director of Federal Bureau of Investigation (FBI). ${ }^{[45]} \mathrm{He}$ led that post for 48 years until he died in 1972. He covered prohibition (1920 -1933), the great depression (1929-1941), World War II (1939-1946), the cold war (1947-1991), the Korean War (1950-1953), and the Vietnam War (1955-1975). Further, he organized a national laboratory for forensic services in the USA.

Ultraviolet (UV) radiation (Fig. 26) was discovered in 1801 when the German physicist Johann Wilhelm Ritter. UV radiation can cause chemical reactions and causes many substances to glow or fluoresce. Therefore, in the 1950s, it is used to identify the latent (non-visible) stains, semen stains, fingerprints etc. $^{[46]}$ 


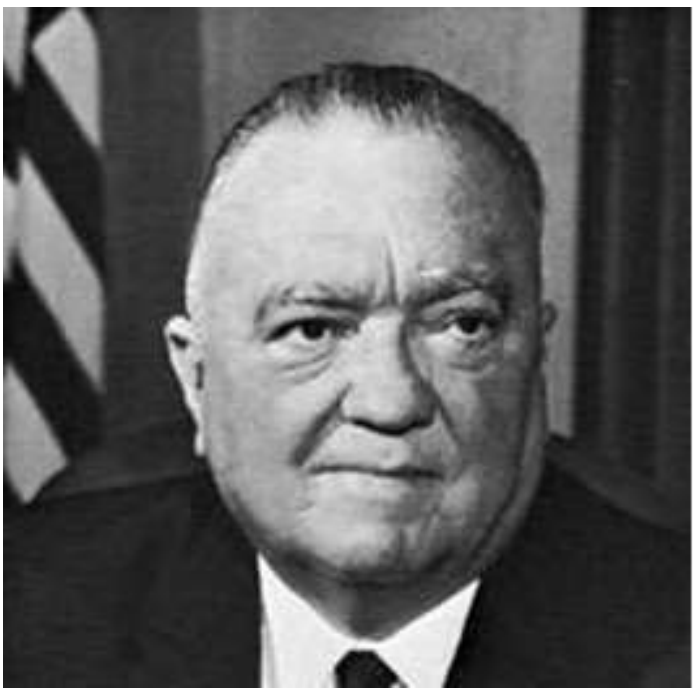

Figure 25: J Edgar Hoover

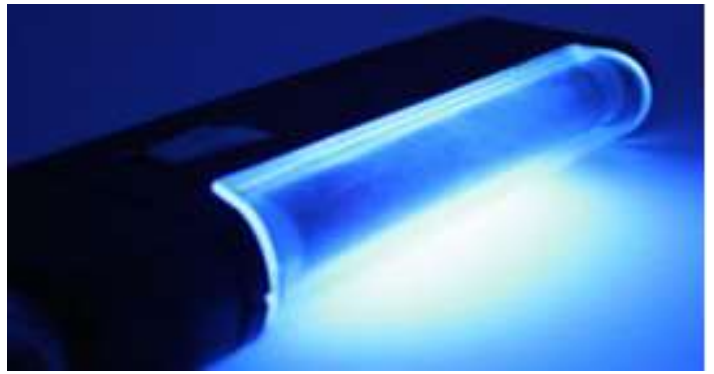

Figure 26: UV light

The new 'X-Ray Fluorescence (XRF)' technique was introduced in the 1950s and can identify toxins without damaging the analytes. It is a huge development in the toxin analysis. ${ }^{[4]}$

Sir Sydney Smith (1883-1969) was one of the preeminent medico-legal specialists of his days. As a leading forensic pathologist, Professor of Forensic Medicine and Dean of the Faculty of Medicine at the University of Edinburgh from 1928 until his retirement in 1953, his medico-legal skills were well known $^{[48]}$.

Sir Alec John Jeffreys (Fig. 27), is a British geneticist, who developed techniques for DNA fingerprinting and DNA profiling. It is now used worldwide in forensic science to assist police detective work and to resolve paternity and immigration disputes. He is a professor of genetics at the University of Leicester, and in 1994, he was knighted for services to genetics. In 1986, as a result of collaborative efforts between the British Home Office Forensic Science Service and Prof. Jeffreys, the murderer of two English schoolgirls (Linda and Dawn) was identified using DNA. That was the first court case where DNA was lead as an evidence. ${ }^{[49]}$

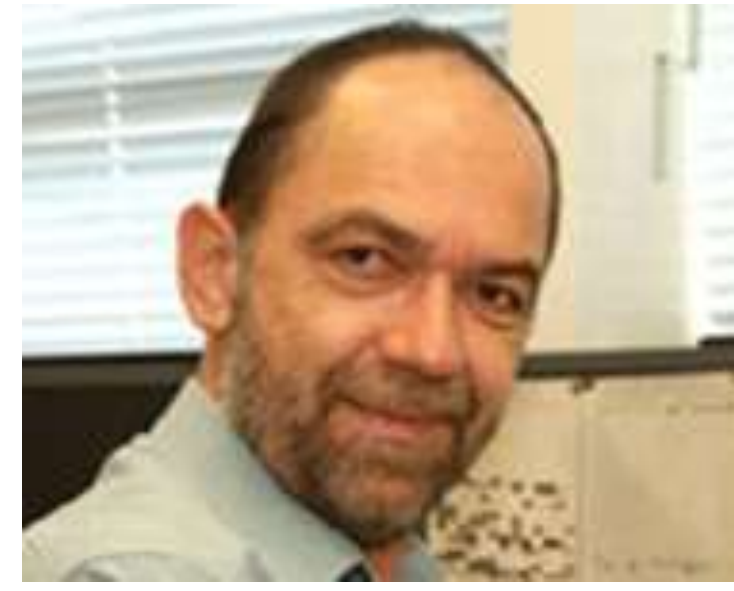

Figure 27: Sir Alex Jeffreys

\section{Medico-legal services in Ceylon (Sri Lanka)}

Sri Lanka has inherited its current legal system from the Roman-Dutch law, but medico-legal services of Ceylon appeared to be commenced with the establishment of health services for the general public by British colonial rulers. The Portuguese, who approached the island in $16^{\text {th }}$ century did not introduce their laws in the coastal regions they controlled, instead, they were more interested in spreading their Roman Catholic religion. With the Dutch gaining control of Sri Lanka, primarily in the coastal regions, Roman-Dutch law gained a presence in the country. ${ }^{[50]}$

The kingdoms of Sri Lankan Monarchy lasted over 24 centuries from $400 \mathrm{BC}$ and the King reckoned to be the supreme administrative and legal authority of the entire island. According to inscriptions of 100 BC -100 AD, a person called Vohara from North East is reckoned to be the first Sinhalese legal expert in ancient Lanka. ${ }^{[51]}$ However, it is not clear that Vohara is a self-learnt expert or an officer designated by the King.

The law and order have been administered through government officers appointed by the King, called Adigars, Robert Knox termed them Chief Judges, and his subordinating officers called Disaves, Vidanes, Liyanaralas, Mohottalas and Korales. All People have liberty in default of Justice to appeal to these Adigars, or if their causes and differences are not decided by their Governours according to their minds. ${ }^{[52]}$ The chronicles indicate that justice being administered through forums like Gamsaba (village council), Ratasabha (District Council) Mahasabha (central forum) etc. and the King himself sat in judgment at certain occasions. During the time of queen Kalyanavati (1202-1208), in fact, the time when Galen was navigating medicine in Egypt, a military commander named Ayasmantha compiled a book on law. There was a 
formal set of laws. Inscriptions such as Vevalketiya inscription of Mahinda IV (956-972) and the Kondavattavan pillar inscription of Dappula IV (924-935) confirm that the laws were written laws. ${ }^{[53]}$ The descriptions contained matters like manslaughter not amounting to murder, theft, alimony payments etc. The Vevalketiya inscription and Kondavattan inscription contain writings about serious offenses like murder, assault, theft, robbery and effacing of band marks etc., and punishments of including fines, diminished responsibility fines for accidental cases, torture, death by drowning or compression with an elephant. ${ }^{[54]}$

There are many references in literature and inscriptions to the administration of law and courts systems in ancient and medieval Sri Lanka including primary sources like Mahavamsa, Pali chronicles, commentaries,

Samantapasadika, Vamsatthappakasini, and Sinhala texts such as the Pujavaliya, Saddharmarathnavaliya and Saddharmalankaraya. ${ }^{[5]}$

The Mahawansa chronicle chapter VII describes about the first king of Sri Lanka, king Vijeya who paid alimony of 1000 "Kahapanas" and separate from his queen Kuveni for abandoning her with two children. ${ }^{[56]}$ The punishments for sexual offenses too have been listed in an ancient inscription where sex with a Queen appeared to be the most serious sexual offense that attracts brutal punishment of being boiled alive.

Written sources from the $5^{\text {th }}$ century $\mathrm{AD}$ and later centuries testify that Ayurvedic medicine, acupuncture and surgery were known in ancient Sri Lanka. Buddhist monks in ancient monasteries used to practice medicine and do so until the present day, and some ancient techniques are still used. ${ }^{[57]}$ The Silk Roads played an important role in spreading medical knowledge.

In spite of having well established medical fraternity represented by Ayurveda physicians with selfderived ethical principles of medical practice, there were no records about rendering physicians' services for legal proceedings and judicial authorities of olden Lanka had acted on lay evidence and common sense while inquiring and delivering judgments. Virchow Rudolf who studied indigenous tribes in Ceylon has made significant remarks about legal affairs in the country. ${ }^{[58]}$

Timeline comparison of the evolution of law and medicine in Sri Lanka with world situation

\begin{tabular}{|l|l|l|}
\hline World & Time & Sri Lanka \\
\hline Cave of Lascaux & 15,00 & First human civilizations \\
& $0 \mathrm{BC}$ & in caves \\
\hline $\begin{array}{l}\text { Imohtep was } \\
\text { practicing in Egypt }\end{array}$ & 3000 & \\
\hline
\end{tabular}

\begin{tabular}{|c|c|c|}
\hline $\begin{array}{l}\text { Code of Hammurabi } \\
\text { is created } \\
\text { Dharmasastra } \\
\text { chronicle is written in } \\
\text { India }\end{array}$ & $\begin{array}{l}2000 \\
\mathrm{BC}\end{array}$ & \\
\hline 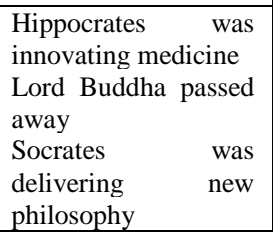 & $\begin{array}{l}500- \\
300 \\
\mathrm{BC}\end{array}$ & $\begin{array}{l}\text { First Kingdom by } \\
\text { "Vijaya" was established }\end{array}$ \\
\hline $\begin{array}{l}\text { Scientific discoveries } \\
\text { by Archimedes } \\
\text { Herophilus and } \\
\text { Erasistratus performs } \\
\text { human dissections }\end{array}$ & $\begin{array}{l}300- \\
100 \\
\mathrm{BC}\end{array}$ & $\begin{array}{l}\text { Establishment of } \\
\text { monastic hospitals for the } \\
\text { general public by ancient } \\
\text { Sri Lankan Kings }\end{array}$ \\
\hline $\begin{array}{l}\text { The assassination of } \\
\text { Caesar }\end{array}$ & $\begin{array}{l}100- \\
0 \mathrm{BC}\end{array}$ & $\begin{array}{l}\text { First legal expert 'Vohara' } \\
\text { exists }\end{array}$ \\
\hline $\begin{array}{l}\text { Galen's era of } \\
\text { medicine } \\
\begin{array}{l}\text { Materia Medica is } \\
\text { released in China }\end{array}\end{array}$ & $\begin{array}{l}0 \\
200 \\
\mathrm{AD}\end{array}$ & \\
\hline $\begin{array}{ll}\text { Hardly } & \text { any } \\
\text { development }\end{array}$ & $\begin{array}{l}400- \\
1300 \\
\text { (Medi } \\
\text { eval } \\
\text { period } \\
\text { ) }\end{array}$ & $\begin{array}{l}\text { The Mahawansa, a written } \\
\text { chronicle on the history of } \\
\text { Sri Lanka is started } \\
\text { around } 460 \mathrm{AD} \text {. } \\
\text { Creation of inscriptions } \\
\text { Kondavattavan pillar, } \\
\text { Vevalketiya inscription } \\
\text { etc., by Sinhalese Kings, } \\
\text { that contained many legal } \\
\text { and social regulatory } \\
\text { provisions. }\end{array}$ \\
\hline $\begin{array}{l}\text { Renaissance of } \\
\text { Europe (1300) - } \\
\text { advancement of arts, } \\
\text { poets, dramas etc. } \\
\text { The industrial } \\
\text { revolution of Europe } \\
\text { (the 1400s) - regained } \\
\text { the development of } \\
\text { the forensic science. } \\
\text { First legal autopsy in } \\
\text { Bologna } \\
\text { Paracelsus was } \\
\text { formulating new } \\
\text { concept in toxicology }\end{array}$ & $\begin{array}{l}1300 \\
- \\
1500\end{array}$ & $\begin{array}{l}\text { A parallel such } \\
\text { development was found in } \\
\text { Sri Lanka too, under King } \\
\text { Parakramabahu the } \mathrm{VI}^{\mathrm{th}} \text {. }\end{array}$ \\
\hline $\begin{array}{l}\text { The release of } \\
\text { German Penal Code } \\
\text { Human studies by Da } \\
\text { Vinci } \\
\text { Publication of } \\
\text { "Quaestiones } \\
\text { medico-legales" in } \\
\text { Italy } \\
\text { Publication of De } \\
\text { Humani Corporis } \\
\text { Fabrica by Vesalius }\end{array}$ & $\begin{array}{l}1500- \\
1600\end{array}$ & $\begin{array}{l}\text { State body into the } \\
\text { investigation of deaths ' } \\
\text { Sakki Balanda' was in } \\
\text { force during Kandyan } \\
\text { Kingdoms }\end{array}$ \\
\hline \begin{tabular}{l}
\multicolumn{3}{|c|}{ Clinico-pathological } \\
dissections by \\
Morgagni
\end{tabular} & $\begin{array}{l}1600- \\
1700\end{array}$ & $\begin{array}{l}\text { Dutch invasion and } \\
\text { introduction of Roman- } \\
\text { Dutch laws }\end{array}$ \\
\hline $\begin{array}{l}\text { Academic } \\
\text { publications on legal } \\
\text { medicine by Casper } \\
\text { Orfila was founding } \\
\text { forensic toxicology. } \\
\text { Devergie had } \\
\text { published Medecine } \\
\text { legale, theorique et } \\
\text { pratique. } \\
\text { Establishment of } \\
\text { Forensic medicine in } \\
\text { UK by Taylor. }\end{array}$ & $\begin{array}{l}1700- \\
1900\end{array}$ & $\begin{array}{l}\text { Establishment of public } \\
\text { hospitals and teaching } \\
\text { legal medicine in } \\
\text { Colombo medical school. } \\
\text { Introduction of Coroner } \\
\text { system by British colonial } \\
\text { rulers. }\end{array}$ \\
\hline
\end{tabular}


However, there are several historical accounts that are evident of the existence of a unique death investigating system in Sri Lanka before the Coroner system of England was introduced during the British era. In the ancient Sinhalese kingdom in Kandy (1593 - 1815), among the organs which administered justice such as Gamsabhava, Ratasabhava and the courts of the Royal officials (vidanes, liyanaralas, mohottalas, korales, disaves and adigars) there had been a tribunal by the name of "Sakki Balanda" (Evidence-based Inquiry), composed of the prominent men of the district, which inquired in to sudden deaths. It is stated that the duty of these officials of Sakki Balanda was to find out the cause and manner of death. ${ }^{[59,60]}$

In 1817, on the recommendation of Charles Farell, Deputy inspector general of hospitals British Governor Robert Brownrigg authorized the establishment of a hospital for the poor. Thus Colombo's first modern hospital was established in 1819 at Prince Street in Pettah. The hospital had 100 beds but demand was so high the hospital became overcrowded and a decision was taken to build a new hospital at a 32-acre cinnamon land in Longdon Place. The birth of the General Hospital Colombo at its current location took place in 1864 as the 'successor' to the first civilian hospital under the charge of a single doctor in British Ceylon back in 1861. By 1919, General hospital Colombo had 687 beds including 62 in paying section. ${ }^{[61]}$ The hospital was facilitated with a postmortem room and mortuary. The Colombo Medical School was opened in 1870, adjacent to the main hospital (female surgical ward today), by the then Governor Sir Hercule Robinson. In 1873, with the introduction of the new prospectus for undergraduate training, Dr Vanderstraaten took over the lecturing on Materia Medica and Medical Jurisprudence. ${ }^{[62]}$

The proper death investigation system in Sri Lanka was originally established in 1883 and is a modified model of the British coroner's system. ${ }^{[63]}$ With establishment and expansion of state-owned hospital network in Sri Lanka, doctor in-charge [District Medical officer] of the medical establishment became a virtual expert on medico-legal matters as well. During the early nineties, due to lack of infrastructural and transport facilities, at times DMO supposed to travel considerable distances after clinical work and conduct postmortem examinations at the scene. ${ }^{[64]}$ Dr S Sinnathurai MD, former Judicial Medical Officer Colombo 1935 - 1945, is the first qualified medico-legal expert of the country, followed by Dr. GS de Saram and Dr. WDL Fernando. The establishment of Medico-Legal Society of Ceylon in December 1937, an umbrella for all the stakeholders involves in criminal justice, is a landmark event of development of Sri Lankan forensics. Further, the establishment of the College of Forensic Pathologists of Sri Lanka in the year 2000 was another landmark event of the Forensic Medicine in Sri Lanka.

\section{Conclusive remarks}

There are reliable historical accounts that flickers of legal medicine existed even in olden human societies dated $1500 \mathrm{BC}$. The examination of corpses have been instituted by ancient scientists and physicians mainly for the morbid anatomical and clinic-pathological purposes and then have been adapted for legal requirements. In ancient Sri Lanka since $500 \mathrm{BC}$, many years prior to the invasion of western colonial rulers, there were common laws to maintain good governance and social order. However, legal matters appeared to be settled by persons with judicial power applying evidencebased common sense, and native physicians were never called upon as experts until the establishment of Roman-Dutch legal framework.

\section{References}

1. Stearns PN. Why study history?. American historical association. accessed in 1998. Available at https://www.historians.org/about-aha-andmembership/aha-history-andarchives/historical-archives/why-study-history

2. Medical Jurisprudence. Date accessed 15 May 2018. available at https://en.wikipedia.org/wiki/Medical_jurispru dence

3. Lamberg-Karlovsky C. C, Sabloff JA. Ancient Civilizations: The Near East and Mesoamerica. Central America: Benjamin-Cummings Publishing; 1979.

4. Smith S. The history and development of forensic medicine, British Medical Journal, March 1951; 1(4707):599-607

PMCID: PMC2068548

5. Ho, PY, Lisowski, FPA. Brief History of Chinese Medicine. $2^{\text {nd }}$ Ed. Singapore: World Scientific Publishing Pte Ltd; 1997

6. Olivelle P, Manu's Code of Law: A Critical Edition and Translation of the MānavaDharmaśāstra. New York: Oxford UP; 2005. p 64.

7. Forensic science-Bioscience topics. Available at http://www.aboutbioscience.org/topics/forensi c-science/ 
8. Forensic science: History. Available at http://science.jrank.org/pages/2821/ForensicScience-History.html"> Forensic Science History

9. Spitz WU. Medicolegal investigation of death, $3^{\text {rd }}$ Ed. Springfield: Charles C Thomas; 1993

10. Vesalius RRR. Herophilus and E] 13 pioneers of human anatomical dissection. 2014 Summer; 20(1):55-8. PMID:25181783

11. von Staden H. The discovery of the body: human dissection and its cultural contexts in ancient Greece. Yale Journal of Biology and Medicine 1992;65(3):223-41.

PMID:1285450

12. Internet encyclopedia of philosophy. Available at https://www.iep.utm.edu/galen/

13. Parker, LA. "A Brief History of Materia Medica," in The American Journal of Nursing, 1915(8)15:650-3.

14. Stenn F. Six hundred years of autopsies. Laboratory Medicine, 1971;2(1):21-5

15. First postmortem. Available at https://www.meduniwien.ac.at/hp/forensicmedicine/general-information/ history-of-thedepartment-of-forensic-medicine-invienna/first-post-mortem/?L=1\#c12829

16. University of Vienna: Forensic Medicine/General Information / History. Available at https:// www. meduniwien.ac.at/hp/1/forensicmedicine/general-information/ history/

17. Robert W. 'Godly States': Confessional conflict and witch-hunting in early modern Germany. Mentalities Vol. V, No. 2, 1988.

18. In memorium. Medico-legal journal, 1885;2: $531-2$

19. Jones R. Leonardo da Vinci: Anatomist. British journal of general practice, 2012; 62(599): 319. DOI:10.3399/bjgp12X649241

20. Gomes Mda M, Moscovici M, Engelhard E. Andreas Vesalius as a renaissance innovative neuroanatomist: his $5^{\text {th }}$ century birth. Arq Neuropsiquaitar. 2015;73(2):155-8 DOI:10.1590/0004-282X20140201
21. Borzelleca JF. Paracelsus: herald of modern toxicology. Toxicological Sciences, 2000;53(1):2-4

PMID:10653514

22. Chaille SE. Origin and progress of medical jurisprudence. Journal of criminal law and criminology 1949;40:397.

23. Casper, JL A Handbook of the Practice of Forensic Medicine Based upon Personal Experience, London: The New Sydenham Society; 1861.

24. Visible proofs; Forensic vies of the body: Biographies: Mathieu Joseph Orfila. Available at

https://www.nlm.nih.gov/visibleproofs/gallerie s/biographies/orfila.html

25. Friederike K. Marie-Guillaume-AlphonseDevergie. Dermatology: Practical and Conceptual 2008;14(1)1798-1879

26. Eckert W. The development of forensic medicine in the United Kingdom from the 18th century. Am J Forensic Med Pathol.1992 Jun;13(2):124-31.

PMID:1510061

27. Mysterious. Mary Blandy. http://www.mysteriousbritain.co.uk/england/ox fordshire/hauntings/mary-blandy.html

28. Casper, JL A Handbook of the Practice of Forensic Medicine Based upon Personal Experience, London: The New Sydenham Society; 1861.

29. Visible proofs; Forensic vies of the body: Biographies: Mathieu Joseph Orfila. Available at https://www.nlm.nih.gov/visibleproofs/gallerie s/biographies/orfila.html

30. Visible proofs. Forensic views of the body. Biographies.

https://www.nlm.nih.gov/visibleproofs/gallerie s/ biographies/orfila.html

31. Wennig R. Back to the roots of modern analytical toxicology: Jean Servais Stas and the Bocarmé murder case. Drug Testing and Analysis. 2009;1(4):153-5. doi: $10.1002 /$ dta.32.

32. Friederike K. Marie-Guillaume-AlphonseDevergie. Dermatology: Practical and Conceptual 2008;14(1);1798-879 
33. Eckert W. The development of forensic medicine in the United Kingdom from the 18th century. Am J Forensic Med Pathol.1992 Jun;13(2):124-31.

PMID:1510061

34. Rosenfeld, Louis, 'Alfred Swaine Taylor (1806-1880), pioneer toxicologist - and a slight case of murder' Clinical Chemistry 1985; 31:7

35. The official site of the Arthur Conon Doyle literary estate. Available at http://www.arthurconandoyle.com/

36. Francis Galton. http://www.galton.org/

37. Rous P. "Karl Landsteiner. 1868-1943". Obituary Notices of Fellows of the Royal Society. 1947;5 (15): 294-226.

Doi: htttp://doi.org/10.1098/rsbm.1947.0002.

38. Visible proofs. Forensic views of the body. Biographies. Alphonse Bertilon. available at https://www.nlm.nih.gov/ visibleproofs/ galleries/biographies/bertillon.html

39. Mikhail Tswett - inventor of chromatography method. Available at http://www.worldofchemicals.com/213/chemis try-articles /mikhail-tswett-

40. Evence C. The Father of Forensics: How Sir Bernard Spilsbury Invented Modern CSI. London: Icon Books Ltd; 2008.

41. Academy of expert witnesses the Jphn Bolton memorial lecture by The Rt Hon The Attorney General - expert evidence - the problem or the solution? The role of expert evidence and its regulation. 25 January 2007. Available at https://web.archive.org/web/20070930143258/ http://www.attorneygeneral.gov.uk/attachment s/Attorney\%20General\%27s\%20John\%20Bolt on $\% 20$ Memorial\%20Lecture $\% 20$ $\% 20$ Expert $\% 20$ Evidence.pdf

42. Sellers C. Albert Sherman Osborn: Questioned Document Pioneer. American Bar Association Journal. 1959; 45(12): 1285-7, 1334-6

43. Wennig R. Back to the roots of modern analytical toxicology: Jean ServaisStas and the Bocarmé murder case. Drug Testing and Analysis. 2009;1(4):153-5.

DOI: doi: 10.1002/dta.32.

44. Muehlberger CW. Col. Calvin Hooker Goddard 1891-1955 C. Journal of Criminal Law and Criminology and police science. 1955; 46(1): 103-104.
45. J. Edgar Hoover. available at https://en.wikipedia.org/wiki/J._Edgar_Hoover

46. Science Mission Directorate. "Ultraviolet Waves" Mission:Science. 2010. Available at http://missionscience.nasa.gov/ems/10_ultravi oletwaves.html

47. XRF Technology. Available at https://www.thermofisher.com/us/en/home/ind ustrial/spectroscopy

48. Sir Sydney Smith and the development of police laboratories. Royal College of Physicians of Edinburg. Available at https://www.rcpe.ac.uk/heritage/sir-sydneysmith-and-development-police-forensiclaboratories

49. Biography of Professor Sir Alec Jeffreys. http://www2.le.ac.uk/departments/genetics/jeff reys/biography

50. Cooray A. “Oriental and Occidental Laws in Harmonious Co-existence: The Case of Trusts in Sri Lanka". Electronic Journal of Comparative Law. 2008;(12)1:2

51. Paranavithana S. Inscriptions of Ceylon- Vol I. Colombo: Department of Archeology; 1970.

52. Knox R. An Historical Relation Of The Island Ceylon In The East Indies Together With An Account Of The Detaining In Captivity The Author And Divers Other Englishmen Now Living There, And Of The Author's Miraculous Escape. London: Royal Society.; 1861.

53. Peiris K. Legal system in ancient and medieval Sri Lanka. Daily News;21 August 2009.

54. Perera L. The Institutions of Ancient Ceylon from Inscriptions from 3rd Century B.C. to 10th Century A.D. Research thesis 1949.

55. Wimalasena, N.A., 2013. Judicial administration in ancient Sri Lanka, In: Proceedings of the 2nd International Conference on Social Sciences, University of Kelaniya, pp 39.

56. Simplified version of Mahavansa. http://mahavamsa.org/mahavamsa/originalversion/07-consecrating-vijaya/. It is also quoted by HW Cardington on Ancient Coins in Ceylon

57. Premathilaka L. Ancient monastic hospital system in Sri Lanka. International Seminar for 
UNESCO Integral Study of the Silk Roads: Roads of Dialogue "Ancient Trades and Cultural contacts in Southeast Asia". 21-22 January 1991. Bangkok, Thailand.

58. The Veddás of Ceylon, and their relation to the neighbouring tribes. By Professor R. Virchow. Tr. from the German for the Ceylon Asiatic society. Colombo: G.J.A. Skeen; 1888.

59. WijebandaraC. A Critical Analysis of the Present Death Investigation System in Sri Lanka. Available at http://www.academia.edu/17147788/A_Critica 1_Analysis_of_the_Present_Death_Investigatio n_System_in_Sri_Lanka
60. Cooray, L. J. M. An introduction to the legal system of Ceylon. Colombo: Lake House Investments; 1972

61. Fergusson's Handbook and Directory 1920-1

62. Regulations of the Ceylon Medical College, 1912/13:2-3

63. Kodikara S. Over-a-century-old death investigation system in Sri Lanka: an appraisal for reforms. American journal of forensic medicine and pathology. 2013 Sep;34(3):283-5. DOI:10.1097/PAF.0b013e31828ced3b

64. Fonseka M. Great days: Memoirs of a Ceylon Government Medical Officer of 1918- PRC Peterson. Colombo: Social Scientists Association; 2001. 